\title{
RENASCIMENTO E BARROCO - UM PARALELO CONTRASTANTE ATRAVÉS DA PINTURA E DA MÚSICA
}

\author{
José Costa D'Assumção Barros \\ UFRRJ
}

\section{Resumo}

Este artigo busca refletir sobre as relações entre Artes Visuais e Músico no âmbito de momentos específicos da História da Arte, elaborando uma análise comparativa entre a arte renascentista e a arte barroca, examinando as relações entre artes visuais e Música. Os elementos essenciais do estilo Barroco e do estilo Renascentista são considerados em oposição de modo a identificar possíveis similitudes existentes entre os aspectos pictóricos e os aspectos musicais de cada um destes estilos. O artigo parte do pressuposto de que, uma vez que estejam envolvidas pelo mesmo contexto histórico-social, a produção artística visual e a produção artística musical de um mesmo período e sociedade devem trazer elementos fundamentais em comum, e que, de maneira análoga, podem ser percebidas mudanças e rupturas entre as artes visuais e sonoras de dois períodos históricos distintos. Metodologicamente, dialoga-se na parte inicial do artigo com o sistema conceitual proposto por Wölfflin para análise de estilos artísticos. Na parte final do artigo dialoga-se teoricamente com a filosofia nietzscheniana, ao utilizar-se os conceitos de apolíneo e dionisíaco em sua aplicabilidade às artes visuais e à música.

\section{Palavras-chave:}

Arte e Música; Arte Barroca; Arte Renascentista.

Pintura e Música apresentam uma longa história de diálogos e entrecruzamentos, como expressões artísticas distintas mas que podem interagir uma sobre a outra. Das concepções estéticas de pintores como Kandinsky e Braque, que vislumbravam relações íntimas entre a imagem e o som, até as experiências de compositores como Alexander Scriabin, que chegou a imaginar um piano foto-cromático que além de sons emitisse feixes luminosos de diversas cores, e até fraglâncias perfumadas, não são raros na História das Artes Visuais e da Música os exemplos de

\section{Abstract}

This article attempts to develop a reflection about the relations between visual arts and music in the ambit of specifically historical periods, elaborating a comparative analysis from the renaissance and baroque arts, examining the relations between visual arts and Music. The essential elements of the Baroque Style and of the Renaissance Style are considered in opposition in order to identify possible similarities existent between the pictorial and musical aspects of which one of these styles. In the methodological aspects, the initial part of the article dialogues with the conceptual system considered by Wöfflin for analysis of artistic styles. In the last part of the article, it is establish a dialogue with the Nietzsche's Philosophy in the use of the concepts of apolinian and dionysiac.

Keywords:

Art and Music; Baroque Art; Renaissance Art.

artistas que, quando não transitaram entre as duas artes, freqüentemente conceberam íntimas relações entre ambas.

As artes Visuais, entre as quais a Pintura, e a Música, têm naturalmente cada qual as suas especificidades. Podemos lembrar aqui uma clássica oposição que será retomada mais adiante: o contraste entre o princípio apolíneo e o princípio dionisíaco (Nietzsche, 1996). Apolo, deus do Sol e pai de toda imagem, é o deus por excelência das artes plásticas, no sentido de que estas são potencialmente (embora não necessariamente, 
como provarão várias correntes da arte moderna) artes figurativas. Dionísio, o deus da embriaguez, ao menos no âmbito das proposições nietzschinianas, é também o deus da Música - a arte não-figurativa por excelência ${ }^{1}$. Essas relações são na verdade apenas primárias, referentes a um plano de definições mais amplas, uma vez que tanto a pintura como a música movimentam dentro de si, como veremos, princípios apolíneos e dionisíacos. De qualquer maneira, o projeto de estabelecer uma ponte entre a pintura e a música (e de certa maneira entre o apolíneo e o dionisíaco), tem fascinado diversos artistas em todos os tempos.

Por outro lado, grandes teóricos e estudiosos da arte têm se empenhado em examinar as íntimas relações que podem ser estabelecidas entre a Música e as diversas modalidades de expressão artística que lidam com imagens. A busca da compreensão através de uma Estética mais abrangente, que considere a Pintura, a Escultura, a Arquitetura e a Música de uma mesma época, ou ainda incluindo outras formas de expressão como a Literatura e a Filosofia, tem sido meta de diversos historiadores da cultura e filósofos da arte. Apenas para registrar um exemplo célebre, entre outros tantos, podemos citar o esforço de Erwin Panófsky, em uma obra escrita em 1951, com vistas a enxergar as relações possíveis entre a Arquitetura Gótica e a Escolástica, relacionando Arquitetura, Artes Visuais e Filosofia em um único movimento ou sistema de pensamento e criação ${ }^{2}$.

O principal objetivo deste ensaio será o de entrecruzar algumas categorias de análise, já tradicionais para a interpretação das obras de arte visuais e sonoras, com vistas a examinar certos padrões estéticos e estratégias representativas (na pintura e na música) de um mesmo período - tendo sido escolhidos para este paralelo comparativo os momentos Renascentista e Barroco da História da Arte. A discussão envolverá a apropriação de alguns conceitos fundamentais da História da Arte e da Música e, ao mesmo tempo, a consciência dos limites a que se restringem os estudos sobre a arte quando utilizam estas formulações conceituais. Neste sentido, partiremos de uma reflexão inicial sobre o uso de categorias generalizadoras no estudo da História da Arte, indagando simultaneamente sobre os limites de seu uso e a sua necessidade.
Desde que homem começou a empreender esforços no sentido de compreender racionalmente a Arte, seja a de sua época ou a de outras épocas, têm sido elaboradas categorias e conceitos que, de uma maneira ou de outra, são quase sempre redutores e generalizadores. Por diversas razões, as categorias e conceitos estabelecidos racionalmente freqüentemente incorrem em limitações, particularmente quando estes são concebidos como operacionalizações para compreender os fenômenos artísticos. Em primeiro lugar, isto ocorre porque a Arte possui também um aspecto "não-racionalizável": ela é também o território do intuitivo, do espontâneo, do surpreendente, da transgressão em relação às normas estabelecidas. Assim, nem o mais completo sistema de categorias e conceitos racionais pode aspirar a compreender a arte em sua totalidade, ou mesmo uma única obra de arte em sua plena singularidade, pois sempre restará aquela dimensão de uma obra artística que não é passível de ser compreendida conceitualmente.

Em segundo lugar, qualquer sistema de categorias e conceitos - bem como qualquer modelo de racionalização - é, em última instância, histórico. Vale dizer, e é já mesmo um truísmo nos dias de hoje ressaltar isto, qualquer perspectiva do homem sobre o próprio homem é antes de mais nada produto de sua época e de seu ambiente cultural, sendo esta perspectiva algo que naturalmente não cessa de se transformar continuamente através de sua passagem pelo tempo. Por isto mesmo, também o olhar do homem de determinada localidade e época histórica sobre a arte de seu tempo ou de períodos anteriores é sempre apenas um dos "olhares" possíveis - sem esquecer que uma mesma comunidade de pensadores pode dar origem a perspectivas interpretativas mais ou menos diversificadas sobre um mesmo objeto de estudo. Dito de outro modo, nenhum conceito ou categoria de análise pode aspirar a ser absoluto. Se isto é fato reconhecido para qualquer campo de conhecimento nos dias de hoje, tanto mais se mostra aplicável ao campo da História da Arte.

Por fim, resta acrescentar que nenhum artista se reduz rigorosamente ao "padrão de excelência" de sua época, havendo mesmo os que criam os seus próprios padrões individuais e se afastam 
em menor ou maior grau da concepção oficial de arte do seu tempo. Exemplos notáveis disto são os pintores renascentistas Hieronymus Bosch (c.1450 - c.1516) e Pieter Bruegel, o Velho (1525 - 1569), cada qual desenvolvendo um estilo surpreendentemente singular em meio ao modelo hegemônico da pintura renascentista. Em que pese os elementos comuns que estes dois pintores tão singulares possam possuir em relação aos demais pintores renascentistas, as suas especificidades e dissonâncias em relação ao modelo de excelência da arte européia renascentista destaca-se de tal modo que não há como não situá-los em posições ímpares na História da Arte. Casos como estes obrigam o analista a indagar constantemente até que ponto uma obra ou artista em questão podem ou devem ser examinados como representativos de um padrão cultural mais amplo.

Estas são as considerações das quais precisamos partir. Toda obra de arte é simultaneamente produto de uma época, de uma cultura, e de artistas individuais - sendo que é no entrecruzamento destas várias linhas de força que o estudioso de arte pode almejar construir modelos explicativos satisfatórios para a compreensão do estilo artístico de uma determinada época e, mais especialmente, de modelos explicativos voltados para a compreensão da produção de artistas específicos localizados em determinada época.

De qualquer forma, se as categorias e conceitos estabelecidos racionalmente são sempre limitadores, é difícil prescindir deles a não ser que se renuncie a uma reflexão sistematizada sobre o fenômeno artístico. Ou seja, a não ser que pretendamos nos recolher ao estado nãoracional de fruição da obra de arte, os conceitos e categorias surgem inevitavelmente, queiramos ou não. E, enfim, contanto que tenhamos plena consciência de sua relatividade, esses conceitos e categorias podem nos ajudar a compreender efetivamente, em maior ou menor medida, certos aspectos da arte.

Um desses sistemas de conceitos para a compreensão da obra de arte foi elaborado por Heinrich Wolfflin no princípio do século XX (WÖLFLIN, 1996). Tal sistema revelou-se bastante eficaz para a compreensão dos modelos artísticos do Renascimento e do Barroco, que foram tratados comparativamente pelo autor tomando-se por base a pintura e a arquitetura (WÖLFLIN, 1990).

Wölfflin estabelece uma tipologia a partir de alguns pares de opostos que iremos discutir a seguir e que são os seguintes: - linearpinturesco; - planar-recessional; - forma fechada / forma aberta; - multiplicidade-unidade. Esses conceitos fundamentais produzem ainda outros desdobramentos que podem ser expressos também em pares, como "estático-dinâmico", "simétricoassimétrico", e assim por diante. É assim que, nesta perspectiva, o Renascimento aparece associado aos conceitos de linear, planar, forma fechada, multiplicidade, e também aos simétrico e ao equilíbrio. Enquanto isso, o modelo barroco circula pelas idéias opostas: pinturesco, recessional, forma aberta, unidade, assimetria, movimento. o que se fará a seguir é aproveitar algumas das categorias desenvolvidas por Wolfflin para estabelecer uma aproximação entre pintura e música dos períodos renascentista e barroco. Quando tais categorias não forem suficientes, recorrer-se-á a outras.

Um dos pares de conceitos propostos por Wolfflin refere-se ao atributo linear, típico da pintura renascentista, em oposição ao pinturesco barroco. É por aqui que começaremos.

Por linear, entende-se que todas as figuras e formas significativas no interior de uma determinada construção artística são claramente delineadas. Cada elemento sólido apresenta limites bem definidos e claros. Desta maneira, cada figura se destaca como se fosse uma peça de escultura - efeito que muito habitualmente é realçado por uma iluminação uniforme, este que é outro recurso tipicamente renascentista. Isto não impede, naturalmente, que certas técnicas desenvolvidas no final do próprio período renascentista tenham começado gradualmente a superar o aspecto linear que predominara na fase mais característica deste estilo de época. Mas esta questão não poderá ser tratada aqui.

A linearidade pode ser comprovada em inúmeros quadros renascentistas. Tomaremos como exemplo o célebre mural A Escola de Atenas, de Rafael ${ }^{3}$.

Neste quadro (figura 1), cada figura ou elemento de arquitetura é bastante claro e passível de ser isolado dos demais com um mínimo de esforço de apreensão. Embora integrados a um conjunto mais 


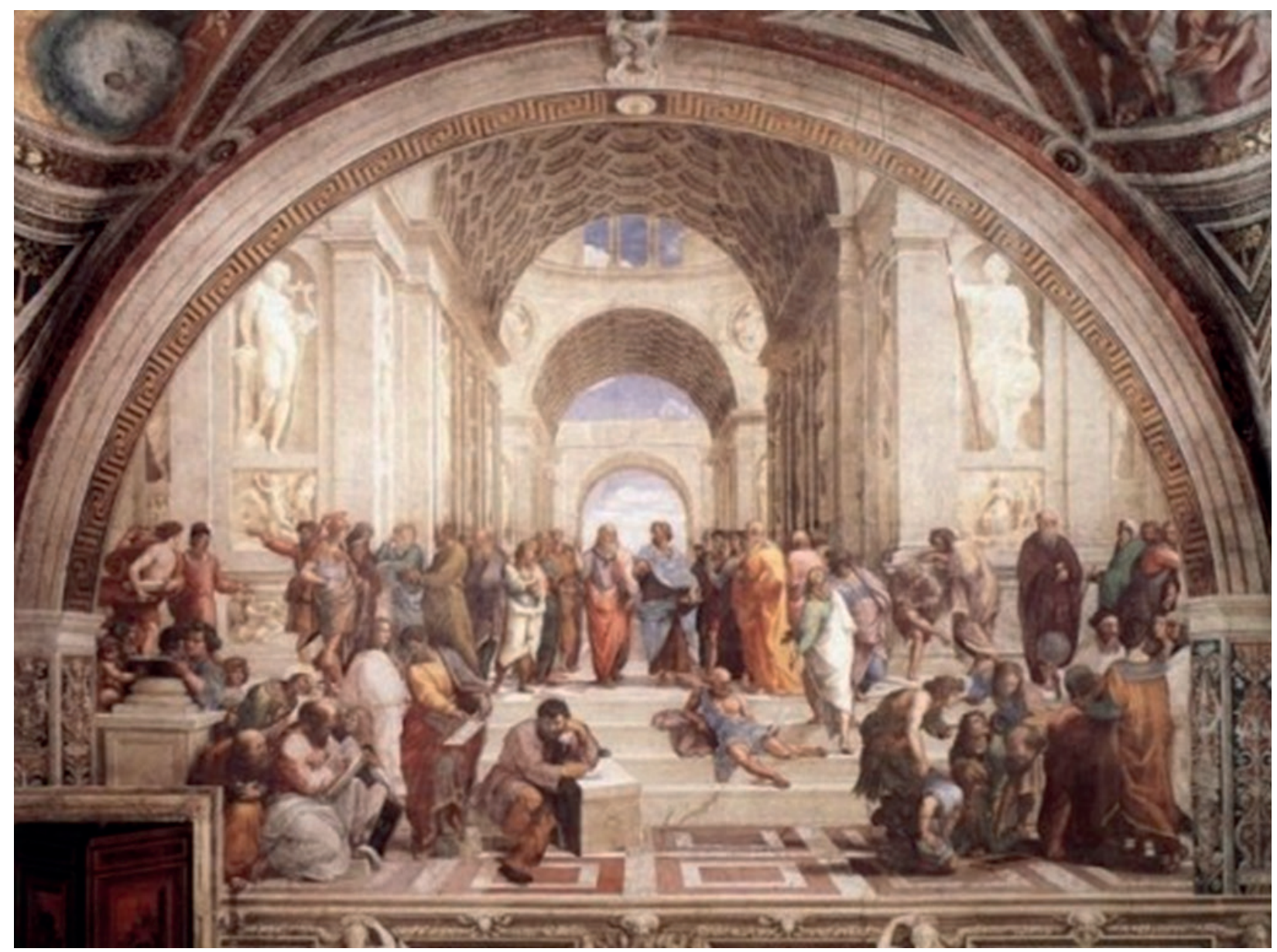

Figura 1 - Raffaelo Sanzio, A Escola de Atenas

1509

amplo que Ihes dá sentido, cada figura ou grupo de figuras neste quadro conserva uma espécie de autonomia. A idéia de Rafael neste mural foi a de homenagear grandes pensadores da Antigüidade Clássica. Nele aparecem representados filósofos antigos de tempos diversos. Platão e Aristóteles aparecem destacadamente no centro do quadro, e também estão presentes diversos outros pensadores clássicos como Sócrates, Diógenes, Pitágoras, Epicuro, Ptolomeu e Euclides.

Não poderemos nos ater a explicar cada um destes personagens, pois isto fugiria aos objetivos deste texto, mas o importante é ressaltar que o observador da obra pode examinar sem dificuldade cada quadrinho particular dentro deste quadro maior. No canto direito inferior do quadro, por exemplo, o matemático Euclides demonstra um teorema para alguns discípulos, e no canto inferior esquerdo quem centraliza um outro grupo é o célebre filósofo Pitágoras. Na parte central inferior aparece uma figura isolada - a de Diógenes, filósofo grego que criticava as posses materiais e que na representação de Rafael aparece relaxadamente esparramado nos degraus. Um pouco à esquerda vemos outra figura isolada, o filósofo Heráclito outro severo crítico da frivolidade humana e que, na representação de Rafael, aparece solitário e pensativo com a cabeça apoiada no braço esquerdo. Cada grupo ou figura isolada funciona, de certa forma, como um quadrinho menor dentro do quadro mais amplo (questão à qual voltaremos mais adiante), e é possível isolar cada elemento constituinte do todo precisamente porque os desenhos são muito bem delimitados. Os contornos das várias figuras e objetos são bem delineados e destacam-se do fundo, os grupos separam-se espacialmente uns dos outros, os elementos de arquitetura os enquadram. Tudo é muito claro e fácil de ser percebido objetivamente.

Apenas como um exemplo desta tendência ao seccionamento interno que se estabelece no padrão de representação da pintura renascentista, 

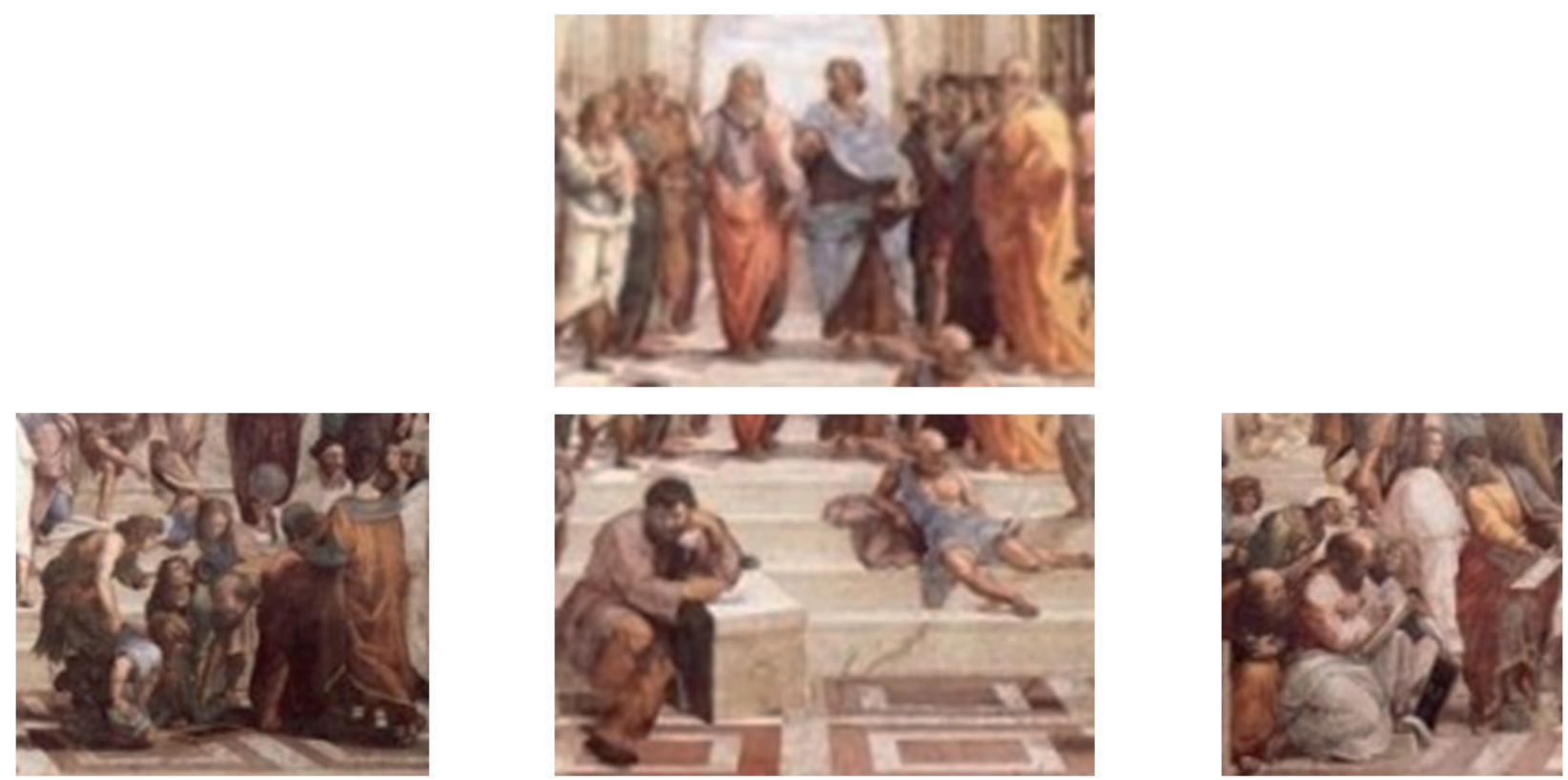

Figura 1.1 - Raffaelo Sanzio, A Escola de Atenas. Cinco detalhes do quadro.

1509

podemos vislumbrar dentro do quadro "A Escola de Atenas" várias seções entre outras, como as exemplificadas acima (figura 1.1).

Cada quadrinho acima selecionado - detalhes do Quadro maior que os constitui em uma totalidade - pode ser contemplado como uma seção à parte, com certo nível de autonomia embora bem integrada no todo. Seccionadas em partes autônomas, estas seções não perdem propriamente o seu sentido. Elas são como partes do quadro que narram a sua pequena história em particular, e todas essas histórias juntam-se em uma história maior que constitui o grande plano narrativo do quadro como um todo. Também é interessante observar que outras maneiras de se dividir o quadro poderiam se apresentar, já com relação aos planos de afastamento das imagens em relação ao observador. Este aspecto será discutido em seguida, quando examinarmos outro aspecto importante das maneiras renascentistas de representação pictórica, e que pode ser denominado representação "planar". Apenas para antecipar este ponto, seria possível pensar aqui em um primeiro mais plano, mas próximo do observador que contempla o quadro, e que se constitui de todas as figuras que se acham ao nível do pé da pequena escada de três degraus. Sentado nas escadas displicentemente, Diógenes situa-se em um ponto que já se coloca a meio caminho em direção ao grande grupo de pessoas que, situadas no patamar mais alto da escada e centralizadas pelas figuras de Platão e Aristóteles, povoam um segundo plano de observação. Atrás deles, iniciam-se camadas de profundidade determinadas pela arquitetura deste grande recinto que seria esta imaginária "Escola de Atenas" criada por Rafael.

Os exemplos acima evocados - seja os seccionamentos que podem ser feitos para a compreensão do quadro na sua superfície, seja os seccionamentos que se referem a planos de profundidade - vêm a nos mostrar que, quando nos pomos a contemplar um 


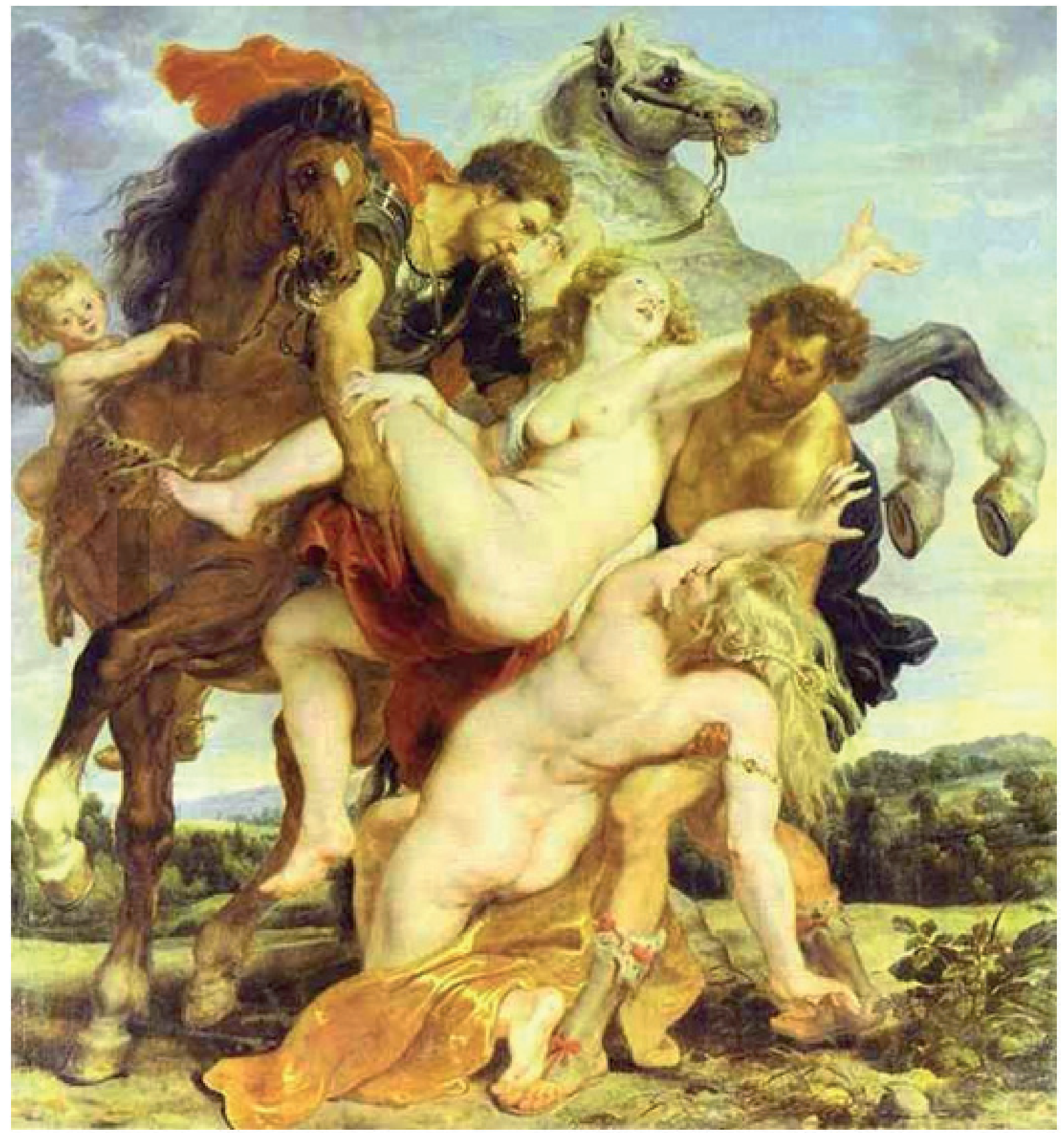

Figura 2 - Rubens, O Rapto das filhas de Leucipo

quadro como este de Rafael, facilmente torna-se possível vislumbrar seus compartimentos internos e planos de afastamento, muito bem delimitados e separados uns dos outros. De igual maneira, cada figura parece ter no seio destas várias microformas que se articulam o seu lugar próprio, separandose de outras figuras e do próprio ambiente que as cerca. Todas se relacionam, mas conservam sua identidade formal, sua cor própria e local.
O contrário disto ocorre nas obras barrocas, das quais daremos como exemplo O Rapto das Filhas de Leucipo, de Rubens ${ }^{4}$, e a Ronda Noturna, de Rembrandt ${ }^{5}$ (figuras 2 e 3). Nestas pinturas barrocas, ao contrário, podemos aplicar o conceito oposto ao "linear": o "pinturesco". As figuras, então, não são uniformemente iluminadas e muito menos isoláveis umas das outras. Antes, fundemse umas às outras - em um caso sendo vistas através de uma luz forte e unidirecional, para 


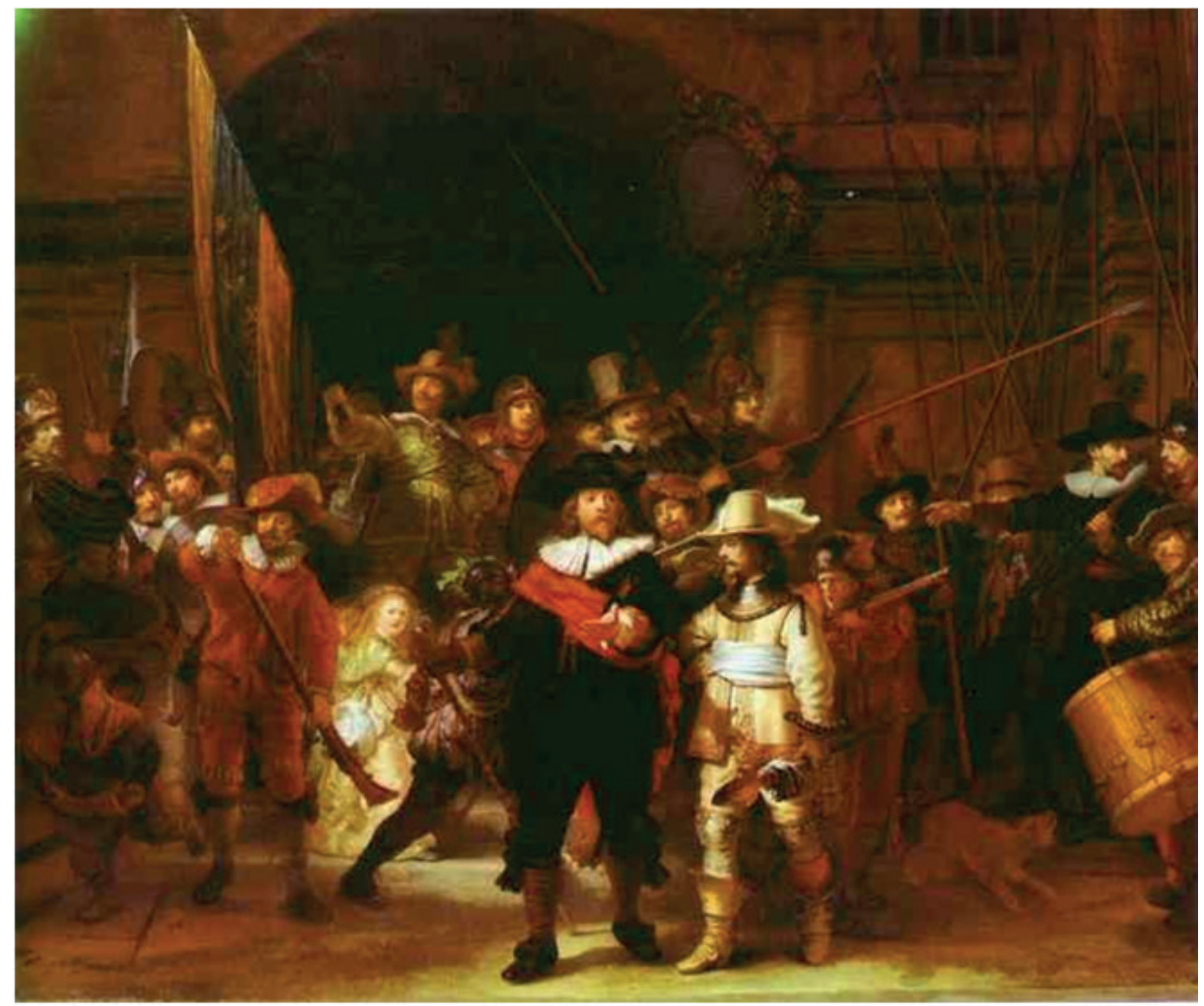

Figura 3 - Rembrandt, Ronda Noturna

considerar o quadro de Rubens, e em outro caso unificadas pela sombra envolvente no quadro de Rembrandt. Esta luz unidirecional ou esta sombra englobante funcionam aqui como poderosos elementos intermediadores entre cada elemento do quadro e o "todo composicional". Assim, o contraste entre sombra e porções de luz no quadro A Ronda Noturna de Rembrandt contribui para realçar ou obscurecer irregularmente um elemento e outro, e ainda para indeterminar os contornos das figuras que acabam se fundindo na sombra sem fronteiras bem definidas.

Outro par dicotômico importante na abordagem proposta por Heinrich Wölfflin para a análise de representações iconográficas figurativas é o que poderemos chamar de "planar-recessional". Nas obras renascentistas, tipicamente planares, identifica-se facilmente, como já foi notado no parágrafo anterior, uma série de planos paralelos que organizam regularmente a profundidade do conjunto de imagens, e nestes planos de composição os vários elementos isolados são distribuídos.

Assim, como se disse, se na Escola de Atenas um primeiro plano é dado pelos grupos e degraus mais próximos ao observador; já o segundo plano desenvolve-se em torno das figuras centrais de Platão e Aristóteles e se estende simetricamente por outros grupos de pessoas e objetos; enquanto isso, o último plano corresponde à arquitetura de fundo que faz o olhar convergir para uma pequena porta aberta para o infinito, perfazendo-se com tudo isto uma organização em três planos paralelos. Estes três planos, aliás, são bem assinalados pela seqüência de arcos e outros elementos da arquitetura, e desde já vale lembrar que era muito comum entre os pintores 
renascentistas (como também o será entre os pintores neo-clássicos do século XVIII) a utilização dos suportes arquitetônicos para criar a ilusão de profundidade e construir a perspectiva.

Tudo se passa de maneira distinta nos quadros de Rubens e Rembrandt. Nestes exemplos barrocos, o princípio de organização se dá em termos de diagonais em recessão. A composição de $O$ Rapto das filhas de Leucipo é dominada por figuras dispostas em ângulo em relação ao plano do quadro e que se afastam ou se aproximam do espectador em profundidade: na esquerda, o Raptor inclinase em direção a uma das mulheres desnudas, mais avançada, e a agarra em uma das pernas. Um pouco mais avançado aparece o outro raptor que agarra a outra mulher desnuda, mais próxima do observador. Mas todas estas figuras estão muito entrelaçadas, de sorte que seria impossível separá-las em planos bem definidos e muito menos em seções isoladas dentro da obra. De maneira análoga, também na Ronda Noturna de Rembrandt as figuras principais parecem se movimentar diagonalmente, agora para a frente e para a esquerda.

A organização recessional tem um desdobramento que é oportuno comentar: ela impede que a percepção da obra seja conduzida através de um padrão de fixidez ou estabilidade. Na segunda parte deste texto veremos que a idéia de 'movimento' é característica não apenas da pintura como também da música barroca. As idéias de estabilidade e equilíbrio na concepção renascentistas, e de movimento nas obras barrocas, também aparecem em decorrência ao terceiro par de conceitos: forma fechada - forma aberta.

A forma fechada é bastante típica do Renascimento: todas as figuras incluídas na Escola de Atenas estão equilibradas dentro da moldura do quadro, ao mesmo tempo em que a composição se baseia em verticais e horizontais que repetem a forma da moldura e sua função delimitadora. Assim, nesta pintura de Rafael as horizontais enfáticas dos degraus contrastam com as verticais das figuras e das paredes que sustentam os arcos. O que já foi comentado acerca das pequenas seções internas que podem ser estabelecidas no interior do quadro vê-se também reforçado por este aspecto. Na verdade, os diversos aspectos que aqui estamos considerando tendem a se reforçar reciprocamente: a forma fechada, a tendência à compartimentação interna, a estabilidade, a organização planar do material visual - estes diversos aspectos interagem uns sobre os outros, são partes integradas de um mesmo sistema de representação pictórica.

Já nas composições barrocas verificamos a ocorrência mais freqüente da forma aberta. A construção em linhas diagonais contrasta então com as horizontais e verticais da moldura e determina relações de distância, trazendo um dinamismo às figuras e a um conjunto que agora não parece mais estar contido simplesmente na estrutura de emolduramento. A moldura, aliás, costuma nas obras barrocas cortar as figuras pelos lados deixando-as pela metade, e em algumas composições as cenas representadas parecem se estender para muito além dos limites espaciais impostos pela moldura, como se quisessem ganhar o infinito.

Por fim, o último par proposto por Wolfflin para a análise de obras renascentistas ou barrocas é o que relaciona multiplicidade e unidade. De certa maneira, estes dois conceitos informam todos os anteriores. Entende-se por multiplicidade, para além do fato de que se multiplicam as temáticas internas que compõem o enredo mais abrangente, o fato já mencionado de que a pintura renascentista é composta de partes distintas e de ambientes relativamente diferenciados. Conforme já vimos, nestes casos a obra apresenta-se internamente seccionada, sendo cada seção plena de sua cor própria, particular e local, e sendo por vezes possível examinar certos grupos e elementos como se fossem pequenos quadros dentro do quadro, separados uns dos outros ainda que mutuamente articulados em uma totalidade maior que unifica a variedade. Para o caso de A Escola de Atenas, já vimos como seria possível subdividir o quadro em quadrinhos menores, cada qual com um subtema particular e destacado mais ou menos claramente das demais seções. Fora o polisseccionamento imediato, os renascentistas tinham ainda outros recursos que contribuíam para isolar os vários elementos em uma multiplicidade de unidades independentes, como era o caso da já mencionada utilização de uma luz difusa em $A$ Escola de Atenas.

Por outro lado, a unidade é o ponto de partida da pintura barroca, muitas vezes obtida por meio 
da luz forte dirigida. Em O Rapto das Filhas de Leucipo, já vimos como todas as unidades estão inextricavelmente interligadas, de modo que nenhuma delas poderia ser isolada. Pode-se dizer que, enquanto o artista renascentista parte da variedade (multiplicidade) e busca uma unidade a partir desta variedade, o artista barroco percorre o caminho inverso: ele parte de uma concepção unitária da obra de arte e logo procura estabelecer uma variedade na unidade. Os elementos internos a uma composição barroca são fundamentalmente ligados, se entrelaçam e invadem uns aos outros, estão como que profundamente mergulhados em uma unidade maior que pode ser obtida por recursos diversos, que vão desde a unificação pela luz ou pela sombra até a unidade estabelecida a partir do movimento, do entrelaçamento dos planos recessionais ou da fusão de contornos que se perdem em sombras, tornando pouco nítidas as fronteiras e delimitações de elementos que de outra forma poderiam ser isolados como nas pinturas renascentistas. Comprove-se essa série de recursos nos exemplos já citados. No Rapto das Filhas de Leucipo, temos o recurso do entrelaçamento dos vários elementos, que adicionalmente são unificados por um movimento contínuo; e na Ronda Noturna, de Rembrandt, a sombra e o fundo escuro são os grandes elementos unificadores.

Uma reflexão sobre o conjunto de categorias associáveis ao barroco nos mostra que a grande característica da pintura barroca é a sua concepção unitária da obra de arte, uma vez que os demais aspectos já examinados - o pinturesco, o recessional, a forma aberta, o movimento, a assimetria - contribuem antes de qualquer coisa para impulsionar a imagística barroca em direção a uma unidade final que ao mesmo tempo é seu ponto de partida. Tal concepção unitária também pode ser facilmente verificável na escultura ou na arquitetura, e mesmo na concepção urbanística (não esquecendo que as grandes avenidas, estas vias unificadoras do conjunto urbano proliferam principalmente a partir das cidades barrocas). Mas também na Música poderemos examinar essa concepção unitária da obra de arte barroca, bem como sua contrapartida renascentista fundamentada na variedade. Veremos isto em seguida 6 .
Tal como ocorre de modo geral com a pintura renascentista ou com a construção arquitetônica do mesmo período, também a música do Renascimento apresenta freqüentemente formas polisseccionadas. Ou seja, neste caso as diversas partes internas a uma peça musical são facilmente identificáveis e se apresentam como unidades menores, embora obviamente interligadas. Por vezes, a separação entre as múltiplas seções é tornada nítida mediante o recurso rítmico, percebendo-se uma cadência muito clara ao final de cada seção que a separa da seção seguinte. Essas cadências são freqüentes nos madrigais e chansons - dois gêneros polifônicos tipicamente renascentistas. Em gêneros em que não ocorrem cadências muito nítidas, e em que as múltiplas seções como que se entrelaçam (tal como ocorre nos motetos), o polisseccionamento é contudo perceptível porque cada uma das seções tem como que uma "cor" própria e particular, de maneira análoga ao que ocorreria em uma pintura renascentista em que o autor criasse "nuances" de cor, luz e perspectiva dentro do conjunto maior.

Na música renascentista, o que dá cada seção essa "cor particular" é aquilo que chamaremos de tema. Em um moteto ou uma chanson renascentista, cada seção é gerada por tema um pequeno motivo musical que, enunciado por uma das vozes, é logo repetido pelas demais com ou sem alguma variação, mas sempre em outra altura para que fique caracterizada a textura polifônica e a autonomia das diversas vozes. Vale lembrar que os motetos, madrigais ou chansons são composições para diversas vozes musicais em alturas diferentes que se respondem umas às outras e são ouvidas simultaneamente, freqüentemente com alguma diversificação rítmica que Ihes assegura certa autonomia de umas em relação às outras. A este método de apresentação musical chamamos habitualmente de 'polifonia'. Exemplos clássicos de motetos politemáticos, polifônicos e polisseccionados são os de Josquin des Prés ou de Orlando de Lassus, dois compositores renascentistas mais célebres, respectivamente dos séculos XV e XVI7.

Examinaremos o polisseccionamento da obra musical renascentista a partir de uma análise da composição O Canto dos Pássaros, célebre 
chanson de autoria de Clement Janequim, compositor francês do século XVI ${ }^{8}$.

Antes de adentrarmos a questão formal, convém observar que nesta composição, como em muitas outras, Janequin tematiza a Natureza. Esta é uma tendência perfeitamente integrada ao quadro de atitudes renascentistas e que também aparece em outras formas de expressão artística, nas quais uma nova valorização da natureza faria com esta passasse a ser um tema bem presente na produção pictórica e também concepção arquitetônica.

Conforme poderá ser observado em uma audição atenta de 0 Canto dos Pássaros, Janequim procura imitar musicalmente sons de pássaros através de recursos onomatopéicos, o que é um traço característico de muitas das obras deste compositor. A música é toda "a capela", isso é, para vozes humanas sem o concurso de instrumentos musicais. A linguagem está enquadrada dentro da já citada polifonia imitativa, sendo percorrida por temas musicais que aparecem imitados nas diversas vozes. Como ocorre freqüentemente nas chansons, além de serem distinguíveis temas particulares que separam por contraste as várias seções, ocorrem também cadências muito nítidas ao final de cada uma delas, o que facilita a delimitação das várias seções. Já vimos que este traço - a delimitação mais ou menos clara de seções internas - é muito característico da concepção artística do Renascimento, manifestando-se também nas artes visuais do período.

A estrutura musical de Le Chant des Oiseaux pode ser explicitada pelo esquema formal abaixo:

\section{A B A C A D A E A F A G A}

Note-se, a partir do esquema bastante simples proposto acima, que a música é dividida em múltiplas seções, cada qual representada por uma letra, sendo que as seções ímpares são similares musicalmente e por isso foram representadas pela mesma letra A. Por outro lado, as seções pares são distintas não só das seções do tipo $A$ como também entre si, e por este motivo foram representadas por letras distintas ( $, C, D$, etc....). Em uma obra musical, as partes internas vão obviamente se sucedendo no tempo, uma depois da outra e assim sucessivamente, de modo que neste caso o ouvinte escuta a parte $A$, logo depois a parte $B$, volta a escutar a parte $A$, escuta a parte $C$, e assim por diante. Aliás, uma diferença entre a obra musical e a pintura é precisamente a de que, na Música, ocorre a passagem da forma através do tempo - como se uma história estivesse sendo contada através de sons - enquanto na pintura a forma é toda exposta de uma única vez para aquele que observa um quadro. Vale dizer, neste último caso as partes ou seções da obra são regiões do espaço pictórico que, por um motivo ou outro, se destacam das outras regiões (ou tematicamente, ou por um efeito de sombra e luz, o por um predomínio de certa cor, ou através de recursos vários de perspectiva, ou mesmo em virtude de sub-campos temáticos gerados pelas figuras representadas). Já na música, as partes se sucedem no tempo e são identificáveis através de mudanças mais ou menos perceptíveis no padrão de sonoridade. A forma musical, poderse-ia dizer, produz ambientes sonoros distintos que podem ser captados com menor ou maior facilidade pelos ouvintes de música, de acordo com o seu próprio nível de competência auditiva.

A forma musical que aparece no Canto dos Pássaros de Janequin não era incomum na arte renascentista, e mais tarde voltaria a ser freqüente no Classicismo da segunda metade do século XVIII - precisamente um estilo de época que voltaria a apresentar suas formas fundamentadas em contrastes temáticos e seções bem definidas (por oposição à concepção unitária do Barroco, tal como veremos oportunamente). No período Clássico da História da Música, que se celebrizou pela contribuição de três dos maiores compositores da música ocidental - Haydn, Mozart e Beethoven - esta forma era especificamente chamada de "forma rondó", e muito freqüentemente aparecia nos últimos movimentos das sonatas, concertos e sinfonias. Por outro lado, se quisermos evocar um campo musical mais recente onde aparece com bastante freqüência uma forma análoga a esta, podemos remeter também aos "chorinhos" brasileiros, onde também é comum este tipo de forma musical fundado na recorrência alternada de uma seção de música que faz as vezes de refrão musical ${ }^{9}$.

A lógica das formas tipo $A-B-A-C-A-D-A-E-A$ é simples: enquanto a unidade da obra é assegurada pela repetição de material musical similar nas seções 


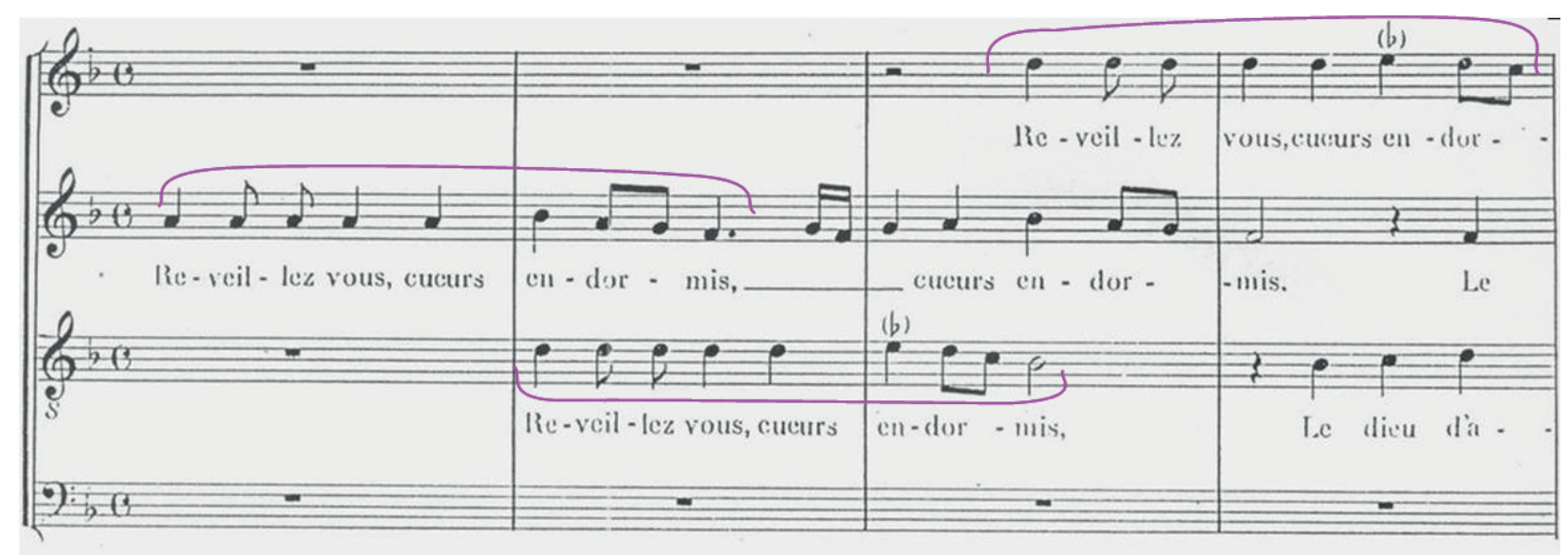

Figura 4 - Trecho inicial da partitura de Le Chant des Oiseaux, de Clement Janequin. Cada um dos pentagramas refere-se a uma das quatro vozes que soam simultaneamente nesta obra musical.

ímpares, as seções pares apresentam material musical sempre novo, com o que se assegura a variedade e o contraste temático ao longo da música.

No Canto dos Pássaros, obra musical que se propõe a traduzir musicalmente o canto de vários pássaros através da linguagem vocal polifônica, isto é feito precisamente nas seções pares contrastantes. Em cada uma delas é imitado um pássaro novo, sempre por meio de recursos onomatopéicos e de um diálogo rítmico entre as várias vozes que traz a estas seções um grande dinamismo e uma surpreendente inventividade. Cada uma dessas seções será diferente de todas as outras, como se tivesse a sua cor própria e particular que é obtida a partir de um novo efeito sonoro.

Em contrapartida, as seções ímpares "tipo A" são similares entre si, e correspondem a trechos musicais onde não aparecem efeitos onomatopéicos. Se examinarmos os compassos iniciais da partitura, veremos que a primeira 'seção $A$ ' - bem como as suas similares - é fundamentada em um motivo temático inicial. O motivo inicial é entoado pelo contratenor (a segunda voz, considerando como primeira a de registro mais agudo) e já no compasso seguinte este é imediatamente respondido pelo tenor (a voz imediatamente mais grave). Mais adiante (figura 4), na segunda metade do terceiro compasso, é a vez da voz superior, e por fim do baixo no sétimo compasso.

O que dá uma identidade a esta primeira seção da música é precisamente esse tema recorrente, que aparece sucessivamente em cada uma das vozes, embora não necessariamente na mesma altura (isto é, se na primeira aparição o tema se inicia com a nota "lá", na segunda aparição, já em outra voz, ele pode se iniciar com a nota "ré", como de fato ocorre no exemplo). Da mesma forma, também será este mesmo tema que mais adiante, nas demais seções do tipo A, assegurará uma unidade mais ampla à obra, apesar da imensa variedade e multiplicidade introduzidas pelas inventivas seções contrastantes que se ocupam de imitar onomatopeicamente o som de pássaros. Todo o segredo desta forma está portanto em alternar o já conhecido com o inteiramente novo. Eis aí como o compositor francês do século XVI conseguiu assegurar 'unidade na variedade'.

Este tipo de forma não é de maneira nenhuma o único que ocorre na música renascentista. Muitos motetos do século XVI, para dar um exemplo, são fundamentados em seções inteiramente contrastantes (A-B-C-D-E-F-G, etc.), cada qual baseada em um motivo novo que lhe dá uma identidade própria. Nesses casos, a unidade da obra costuma ser assegurada pela unidade do texto poético, caso se trate de música vocal. Essa unitextualidade foi aliás uma conquista paulatina da música renascentista: lentamente a politextualidade herdada da música medieval, onde por vezes três ou quatro textos distintos se sobrepunham nas diversas vozes, foi dando lugar à utilização de um 'texto único' para todas as vozes e seções ${ }^{10}$.

É oportuno reconhecer uma diferença formal significativa entre o moteto e a chanson do século 
$\mathrm{XV} \mathrm{I}^{11}$. Enquanto uma chanson como $\mathrm{O}$ Canto dos Pássaros apresenta seções nitidamente pontuadas por cadências rítmicas facilmente perceptíveis auditivamente, já no moteto as várias seções se entrelaçam, encadeando-se sem limites determinados de maneira mais enfática. Isso significa que, enquanto as outras vozes estão terminando o material temático referente à seção anterior, já aparece o tema da nova seção na voz restante. Em seguida, as demais vozes já começam a imitar o novo motivo e já estamos inteiramente no novo ambiente temático. Desta forma, as fronteiras entre uma seção e outra ficam menos claramente definidas que nas chansons e nos madrigais. Em todo o caso, o trabalho politemático é suficiente para estabelecer um polisseccionamento neste gênero tão tipicamente renascentista que é o moteto.

Do que foi visto até aqui, é possível perceber desde já uma similaridade entre a concepção expressa por uma pintura renascentista e a que transparece na música do mesmo período. Em ambos os casos, o artista cria a partir de uma multiplicidade, e então se empenha em assegurar uma unidade com que possa abarcar a totalidade da obra.

Veremos em seguida que um interrelacionamento entre a produção pictórica e musical pode ser encontrado também para o período barroco, porém fundado em uma maneira de conceber a arte diametralmente oposta à que se dava na arte renascentista: agora se irá partir da unidade, desta se desdobrando a variedade buscada pelo artista. É neste aspecto particularmente sutil que a concepção artística Barroca se opõe ao modo de pensar a Arte que aparece mais predominantemente entre os pintores Renascentistas.

Da mesma forma que a pintura barroca é constituída a partir de uma perspectiva de unicidade, também a música barroca está predominantemente erigida em torno do princípio de unicidade composicional.

Serão comuns, aqui, as formas que funcionam como verdadeiros blocos monolíticos, sem que seja possível distinguir muito bem as partições internas. Por vezes as fugas, invenções e prelúdios de fórmula fixa se enquadram nesse caso. Essas são de certa maneira peças musicais unitárias na sua estrutura formal, que não podem rigorosamente ser divididas em seções internas: quando muito, elas permitem entrever ou entreouvir "regiões sonoras" onde se notam como que "nuances" da mesma cor, mas sem que haja efetivamente uma mudança de ambiente que produza uma sensação de contraste.

Também são comuns na música barroca as formas binárias, mas que na verdade são apenas bipartidas do ponto de vista cadencial, e não do ponto de vista composicional. O que permite essa notável unidade composicional de uma peça barroca é que, freqüentemente, toda ela deriva de uma única idéia musical, mesmo nas formas cadencialmente bipartidas.

Tudo se passa como se a maneira barroca de conceber a música esteja obcecadamente ligada a uma necessidade de fazer toda a obra derivar do mesmo elemento, da mesma idéia musical que é impulsionada para frente ao longo de toda a peça, desenvolvendo-se a partir de recursos imitativos e impulsionada pelas modulações que mergulham a obra em um grande movimento contínuo.

Um compositor barroco provavelmente consideraria mesmo despropositada a maneira renascentista de construir peças musicais politemáticas e polisseccionadas a partir das diversas idéias musicais que vão se apresentando sucessivamente. Possivelmente. também lhe pareceria particularmente estranha a "maneira clássica" que surgiria depois do período barroco, pois também os compositores clássicos da segunda metade do século XVIII trariam à tona uma estética fundamentada no contraste de idéias musicais distintas. $O$ período clássico que se inaugura na segunda metade do século XVIII - e que tem em Mozart e Haydn os seus grandes impulsionadores, culminando por fim com a obra de Beethoven - mostra-se aliás como um novo classicismo, o que também ocorre na história da pintura (onde habitualmente se designa este período de neoclássico, reservando a denominação "clássico" para o próprio período renascentista).

Há algo de comum, no que se refere à essencialidade das tendências formais, entre o período Renascentista do início da Idade Moderna e o período Classicista da segunda metade do século XVIII. E ambos contrastam, cada qual à sua maneira, em relação ao estilo Barroco. Tal como 
os compositores renascentistas, os compositores classicistas do século XVIII também tendiam a construir suas formas musicais com base no contraste temático, como se partissem primeiro da multiplicidade contrastante para só depois atingir a unidade composicional da obra através da cuidadosa articulação de suas partes internas em formas como a que vimos anteriormente. Renascentistas e classicistas, enfim, tendiam a construir suas formas musicais a partir de idéias musicais distintas, ou pelo menos através de seções de música de algum modo contrastantes.

Diante dessas duas estéticas a ele opostas, e que o ladeiam cronologicamente, o compositor barroco teria sempre algo a objetar - caso pudéssemos imaginar um debate imaginário entre os três estilos. O barroco, defensor de uma estética da unidade, preferiria em todos os casos guardar uma nova idéia musical para a composição seguinte, e continuar construindo a sua peça musical em torno de um único tema a partir do qual toda a composição gravitaria. As composições politemáticas dos clássicos e renascentistas sempre Ihe soariam como um desperdício de várias idéias musicais que bem poderiam cada qual gerar a sua própria pela musical, ao invés de se amontoar conflituosamente dentro de uma mesma composição. Ou, antes, talvez the ocorresse sarcasticamente que os compositores que precisam abarrotar uma peça de uma pluralidade de temas são aqueles que não se tornaram capazes de desenvolver imaginativamente um mesmo e único tema sem que se perca o interesse da obra.

Já um clássico teria a objetar na música barroca que ela carece daquela "dramaticidade musical" que só pode ser obtida mediante o choque e o contraste de personagens musicais distintos - e às formas unificadas do barroco responderia com formas baseadas em temas contrastantes que se enfrentam musicalmente no decorrer de uma mesma peça (a chamada 'forma-sonata' é um exemplo), ou então com formas ternárias mais simplificadas - tipo ABA - onde a seção intermediária é tão contrastante quanto possível em relação às duas seções extremas.

Naturalmente que tal diálogo entre épocas distintas nunca existiu, e não podemos falar disto senão metaforicamente, uma vez que devemos sempre lembrar que um estilo de época vai como que deslizando para o outro sem que ninguém perceba exatamente como e quando ocorreu a transferência de um padrão estético ou composicional para outro. Voltemos, neste momento, ao período barroco, com suas formas musicais que partem da unidade temática e que somente a partir daí começam a construir a variedade.

Dentre as diversas formas unificadoras do Barroco, poucas conseguiram realizar de maneira tão eficiente o ideal de fazer derivar toda a obra de um elemento fundamental como a FUGA. Essa forma atinge a sua suprema realização na primeira metade do século XVIII com João Sebastião Bach ${ }^{12}$.

O mecanismo de construção da FUGA é relativamente simples. Neste caso, teremos mais uma vez aqui o modo de apresentação polifônico, onde a obra musical envolve planos melódicos separados cantados por vozes separadas. Dito de outra forma, teremos aqui várias vozes musicais que, embora soando simultaneamente, conservam certa autonomia. No caso da Fuga, trata-se de uma polifonia imitativa, onde as várias vozes têm umas com as outras uma relação dialogada. Se por exemplo uma voz expõe um motivo ou um tema, uma outra logo a seguir o reproduz em outra altura, com ou sem modificações essenciais.

Além de polifônica imitativa - que também foi o caso do exemplo musical renascentista apresentado no artigo anterior - a Fuga é monotemática; isto é, existe um único tema que é enunciado logo no início da composição por uma das vozes e que a partir daí vai ser imitado ou desenvolvido de diversas maneiras até o final da peça. Este aspecto monotemático da obra é precisamente o que distingue com maior clareza uma peça musical barroca de uma peça musical renascentista.

Johan Sebastian Bach, seguramente o maior dos compositores barrocos, compôs inúmeras fugas ao longo de sua vida. Podemos dar como exemplo uma das fugas da célebre coletânea O Cravo Bem Temperado (a 'Fuga $n^{\circ} 1^{\prime}$ ). Como toda Fuga (figura 5), veremos aqui uma peça polifônica onde o material temático vai passando sucessivamente de uma a outra voz, de modo que poderemos acompanhar este desenvolvimento através das curvas de apoio acima ou abaixo de cada grupo temático ${ }^{13}$. É importante deixar claro que, quando 

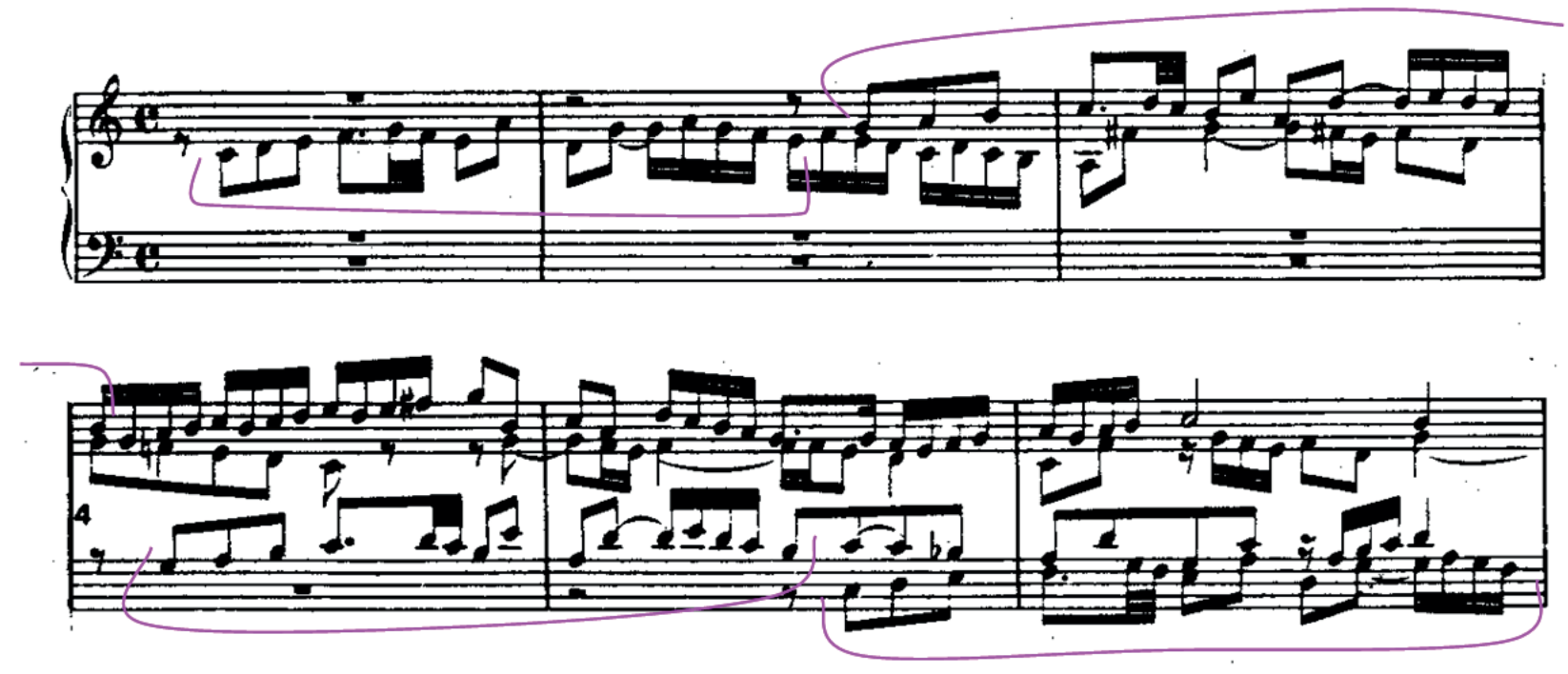

Figura 5 - Trecho inicial da partitura da Fuga n 1, do “Cravo Bem Temperado" de Johan Sebastian Bach.

deixa de entoar o material temático principal, nem por isso uma determinada voz deixa de soar; ao contrário, ela segue adiante, embora em segundo plano, já que apenas vai fazendo soar notas musicais que não tem mais importância temática e apenas complementam a harmonia e a rítmica da composição.

Na Fuga $n^{\circ} 1$, em Dó Maior ${ }^{14}$, o tema ocupa basicamente os dois primeiros compassos; ele soa pela primeira vez na segunda voz e logo a seguir é emitido por cada uma das outras três vozes (primeiro na voz superior, e depois nas duas vozes mais graves). Trata-se no caso de uma fuga a 4 vozes, e o tema é imitado pela voz superior tão logo esta 1 ( voz intermediária conclui sua exposição do tema (isto é, no $3^{\circ}$ tempo do $2^{\circ}$ compasso da partitura) só que em outra altura e outra tonalidade. Somente depois que a voz superior conclui sua exposição do tema, entra em cena uma voz mais grave (a 3( voz) reexpondo-o mais uma vez. As sucessivas exposições do tema ocorrem sucessivamente. Desde que a Fuga seja tocada por um bom pianista (essa fuga foi composta originalmente para cravo) cada entrada do tema deve ficar muito clara e não se misturar às demais notas musicais que soam juntas. 0 instrumentista, aliás, deve estar preparado para ressaltar o tema que por vezes está oculto no conjunto de todas as vozes. Seu trabalho principal deve ser exatamente o de ressaltar o tema que vai sendo alternado pelas diversas vozes - e é a partir desta explicitação da forma que ele pode ser bem sucedido em transmitir um prazer estético ao seu ouvinte. Explicitar cada aparição do tema na voz adequada equivale a contar uma boa estória, a fazer com que o ouvinte perceba muito claramente o que está acontecendo, uma vez que o segredo estético da composição de uma fuga é que ela toda é baseada em um único tema musical.

Um exame atento desta partitura, mas também uma audição acurada, pode mostrar que o tema reaparece ao longo de toda a composição, do início ao fim. Nos momentos em que ele não está soando, via de regra o compositor aproveita para desenvolver um pequeno fragmento musical tirado do próprio tema, seja imitando esse fragmento num habilidoso diálogo entre as diversas vozes, seja modificando-o ligeiramente, invertendo-o, tocando-o de trás para diante, de cima para baixo, ou de tantas maneiras quanto a sua inventividade permitir.

O importante para a nossa presente discussão é que, a partir de uma única idéia musical, o compositor consegue aqui fazer derivar a composição inteira. Ele consegue realizar nesse tipo de forma musical a busca barroca de uma unidade quase absoluta, e não é à toa que as formas fugatas adquiriram tanta popularidade entre alguns compositores barrocos.

A Fuga não é a única forma musical que um compositor barroco tinham à sua disposição para 
obter a almejada unidade primordial, fazendo com que tudo se derivasse de uma única idéia musical. Mesmo nas já citadas formas bipartidas (formas binárias) também podemos identificar claramente o princípio da unidade composicional. Podese tomar como exemplos deste caso tanto as danças que constituíam as suítes barrocas. Uma suíte é uma peça maior que contém pequenas peças dentro dela. Nesta época, estas peças eram derivadas de danças populares que os compositores estilizavam para serem tocadas por um instrumento ou mais. Johan Sebastian Bach também escreveu muitas suítes, e também outros compositores do mesmo período.

As danças incluídas em uma suíte possuíam muito habitualmente uma forma bipartida, no sentido em que se podem notar duas seções separadas por uma cadência bem marcada e que pode ser claramente percebida auditivamente. Na partitura de uma dança de suíte, essa cadência corresponde ao compasso que é antecedido por uma barra dupla. Mesmo o ouvinte que não esteja habituado a ler uma partitura musical, poderá ficar consciente dessa separação entre as duas seções simplesmente ouvindo uma boa gravação.

A peculiaridade da forma binária barroca ( $A B)$ é que, apesar das duas seções bem distinguíveis por esta cesura rítmica, o material musical que as informa é essencialmente o mesmo. Apenas ele aparece na 'parte B' desenvolvido ou alterado, por vezes apenas transposto para outras tonalidades. A mudança de tonalidade na música barroca como que corresponde àquela diagonal recessional que vimos na pintura do mesmo período, e que tinha o papel de dar movimento a toda a composição e impulsioná-la para uma determinada direção.

Em partituras de músicas que possuam esta forma podemos identificar facilmente a identidade de material musical entre as duas seções se examinarmos o primeiro compasso da música e o primeiro compasso da segunda seção, ou mesmo se nos limitarmos a ouvir atentamente uma boa gravação. Em geral, na segunda parte (B) o elemento gerador da composição aparece ligeiramente modificado (às vezes é apenas uma mudança de altura e de tonalidade, mas outras vezes corresponde a uma variação) De todo modo, tratase fundamentalmente da mesma idéia musical, e não de uma nova idéia musical contrastante.
Também é comum ocorra neste tipo de formas musicais um contínuo desenvolvimento do motivo gerador sucessivamente através de diversas tonalidades, até que se retoma a tonalidade inicial e a música se conclui. Note-se que este fluxo contínuo da música, sobretudo nas composições de Bach, transmite-nos uma idéia de movimento que pode ser muito adequadamente associada ao dinamismo da pintura barroca.

Um grande número de formas similares pode ser encontrado no repertório barroco, tomando-se os mais variados compositores. Ao lado das "formas unitárias" como as fugas, as formas binárias com unidade composicional hegemonizam todo um período da composição musical. Estas diversas formas que partem da unidade, e que só a partir desta unidade primordial constroem a variedade, são certamente a contrapartida de formas pictóricas que possuem na luz unidirecional ou no jogo de sombra e luz o seu instrumento unificador.

Algumas palavras ainda devem ser ditas acerca do uso de contrastes no estilo Barroco. O fascínio pelos contrastes - que sabemos ser tão típico da literatura barroca e, logo veremos, também da pintura e da música do mesmo período não deve ser entendido como incompatível em relação à obsessão barroca pela unidade. Deve ser esclarecido, para a melhor compreensão da oposição estética entre o Renascimento e o Barroco, e também deste em relação ao Neoclassicismo do século XVIII, que se a música barroca não lida com contrastes temáticos (isto é, duas ou mais idéias musicais organizando a música) ela lida amplamente com outros tipos de contrastes. É uma criação tipicamente barroca o estilo concertato (o 'concerto' é um gênero musical que lida com a oposição de grupos contrastante em relação à densidade sonora). E a ópera, o espetáculo dramático-musical por excelência, é também invenção barroca.

O que se deve entender em relação à questão do contraste, é que no Barroco os contrastes se dão no mesmo lugar. Nada mais esclarecedor sobre isto do que as esculturas e estátuas de Aleijadinho, o mesmo tempo firmemente ancoradas no chão e expressando o desejo de alcançar o infinito ${ }^{15}$. Nada mais elucidador do que o jogo de claro escuro na pintura de um Rubens ou de um Rembrandt, que se dão literalmente no mesmo lugar, por 
assim dizer, como elementos indissociáveis da composição, amalgamados na unidade da obra. Também na Música, o jogo de tonalidades que se opõem e sucedem uma à outra fazem parte de um mesmo movimento, o contraste timbrístico e de densidades instrumentais é parte de um mesmo movimento unidirecional para a frente, a se perder no tempo da música que, não fosse isso impossível, poderia não se acabar nunca. Os efeitos de espaço infinito, aberto e capaz de extravasar para fora, assegurados tanto pelos pintores como pelos arquitetos barrocos, são os correspondentes desta música que poderia não se acabar nunca.

Ao contrário disto, os contrastes na música e na arte renascentista (e também na música e na arte do neoclassicismo iluminista) estabelecessem-se a partir de lugares distintos. Uma seção musical contrasta com a outra, cada qual com seu lugar muito bem definido no interior da organização musical, da mesma forma que, na pintura renascentista, os vários ambientes se opõem uns aos outros sem se misturarem, cada qual conservando a sua identidade, o seu delineamento e a sua luz própria. Os contrastes renascentistas não se constituem em amálgama, não se estabelecem como tensões no interior de um mesmo ser. Cada seção que contrasta com a outra, na música ou na pintura renascentista, faz isso de seu lugar próprio e específico no interior da obra, como se tivéssemos não um único ser submetido a intensos contrastes (como no Barroco), e sim vários seres que se contrastam uns com os outros no interior de um mesmo eco-sistema. A pluralidade, enfim, é a base da obra de arte renascentista, da mesma forma que a unidade (embora uma unidade que traz os contrastes para dentro de si) é o ponto de partida da obra de arte barroca. Seria talvez possível dizer que, do ponto de vista semiótico, Renascimento e Barroco abordam de maneira distinta os seus pares de contrastes. Enquanto no Renascimento teríamos uma oposição por contrariedade (dois contrários que não se misturam), no Barroco teríamos oposições por contraditoriedades (pólos que interferem um sobre o outro, que são gestados um do outro, e resolvidos dialeticamente em uma unidade maior). Eis aqui dos padrões estéticos que se distinguem perfeitamente, e que marcam tão claramente a sua distância como o "apolíneo" e o "dionisíaco" na filosofia nietzscheniana (Nietzsche, 1872).
A propósito da dicotomia entre o apolíneo e o dionisíaco, poderíamos remeter a estética renascentista a um predomínio de Apolo, o harmonizador dos contrários, e a estética do Barroco a um predomínio de Dionísios, o deus que incorporaos contrários, que se dilacera por dentro mas reatualiza a unidade em um eterno devir. O mergulho dionisíaco, aliás, corresponde à perda da individualização (lembremos que a estética renascentista individualiza explicitamente os seus temas e seções internas, dotando-as de uma luz própria e de contornos muito precisos, que posicionam os diversos temas em uma separação por contrariedade). O dionisíaco, ademais, corresponde à perda de si mesmo (e que metáfora seria mais apropriada para a perda de si mesmo do que a forma "fuga", onde um mesmo tema perdese a cada instante em um passado musical que fica para trás para, em seguida, renascer em uma nova versão em meio ao devir da grande unidade composicional?) $)^{16}$.

A estética barroca tem algo de dionisíaco no sentido de que, já o vimos, é tributária do devir, do movimento, da impulsão para a frente, do eterno trânsito rumo ao infinito das formas abertas. O tema que se impulsiona para a frente na Música Barroca, recria-se e reatualiza-se necessariamente através de novas tonalidades e alturas, de novas versões do mesmo tema (a recriação de um tema musical na sua forma inversa, retrógrada ou retrógrada-inversa, como se o compositor estivesse utilizando tipos diferentes de espelhos, era bastante comum na polifonia barroca). Podem ser citados ainda, como recursos adicionais que se incorporam à Estética do Movimento proposta pela Música Barroca, o uso da técnica do 'baixo contínuo', que através de um instrumento que dita a base da harmonia e do movimento rítmico ajuda a impulsionar a música para diante. Da mesma forma, não é por acaso que a 'modulação' (passagem de uma tonalidade a outra) adquire um desenvolvimento extraordinário no período barroco, sendo oportuno observar que a modulação em uma música barroca é utilizada para também impulsionar a música para diante (ao contrário do que ocorre com o uso da modulação no estilo clássico do século XVIII, que atende ao interesse de criar zonas de contraste harmônico para os diferentes temas musicais, cada qual com a sua cor musical específica). 
Percebe-se, aqui, que a Música Barroca não se encontra de nenhum modo em desacordo com relação à Literatura Barroca, esta que vai buscar na antítese uma de suas figuras e estratégias retóricas preferidas, e nem em relação à Escultura Barroca, que lida habitualmente com tensionamentos diversos. Na Música Barroca, se quisermos ir mais além, teremos, para a realização deste jogo de tensões sob o fundo temático unificado, aspectos específicos que vão desde o já mencionado contraste de densidades sonoras diversificadas (o estilo concertato) até o jogo contrastante de dinâmicas alternando o 'piano' e o 'forte' (uma dinâmica em degraus, ao invés da dinâmica em gradações que seria tão típica do período clássico). Na pintura barroca, da mesma forma, é por demais evidente o jogo que se estabelece visualmente entre o claro e escuro.

Por fim, ainda com relação a esta mesma questão da "multiplicidade", que apontamos constituir o ponto de partida do modo de criação típico dos artistas renascentistas (evoluindo a partir daí para a unidade), é preciso ressaltar a singular relação que também existe entre os artistas barrocos e a multiplicidade, mas de um outro modo. Tal como assinala Germain Bazin, grande estudioso do Barroco, o que interessava ao artista barroco era atingir a apreensão e compreensão da multiplicidade dos fenômenos (BAZIN, 1994, p.2), mas, acrescentemos desde já, isto se dava de uma maneira bastante específica: tratavase de integrar esta multiplicidade em um todo compreensivo - ou, melhor dizendo, parte-se aqui deste todo, desta luz unidirecional que a tudo traspassa, para em seguida atingir a multiplicidade dos fenômenos, envolvendo e adornando a cada um deles de modo especial. Trata-se então, para o caso da arte barroca e da arte renascentista, de duas maneiras distintas de tratar a multiplicidade.

Renascimento e Barroco, enfim - ao menos quando consideramos o padrão de excelência predominante em cada um destes estilos de época - marcam muito claramente o seu mútuo distanciamento estético, embora na verdade o segundo estilo tenha surgido do primeiro ao mesmo tempo em que as sociedades renascentistas deslizavam historicamente para o universo social e político das sociedades barrocas que já se encontram consolidadas em diversas partes da Europa no século XVII.
Os exemplos que estudamos neste ensaio mostram que é possível, enfim, estabelecer um paralelo entre as formas musicais e as estratégias de representação pictórica relacionadas a um mesmo período da História da Arte e da Música, o que pudemos verificar ser especialmente verdadeiro tanto para o período renascentista como para o período barroco. A uma estética que parte da variedade para atingir a unidade - tal como vemos na música e na pintura renascentista - podemos contrastar uma outra estética típica da música e da pintura barroca, onde se parte da unidade para a partir daí atingir a variedade.

É esta unidade de elementos definidores de uma mesma estética - de uma certa ordem ou maneira de conceber a obra de arte - que permite que falemos em "estilos de época" para vários momentos da História da Arte e da Música no Ocidente. Por outro lado, embora este assunto não vá ser desenvolvido aqui, o século $X X$ traria como grande novidade ao padrão de desenvolvimento da História da Arte precisamente o rompimento em relação à unidade dos "estilos de época". Já não encontraremos mais, seja na Pintura ou na Música do século $X X$ em diante, um único grande estilo definidor de uma época, e por esta razão, para estes períodos mais contemporâneos, costumamos falar em "correntes estéticas" diferenciadas que convivem umas com as outras no interior de um mesmo grande período. O Cubismo, o Fauvismo, o Expressionismo, o Abstracionismo e outras "correntes estéticas" da pintura são movimentos contemporâneos, que se dão simultaneamente em uma mesma época. Da mesma forma, o Atonalismo, o Neoclassicismo contemporâneo, os Nacionalismos, e outras tantas correntes que enveredam para experiências musicais ainda mais radicais como o Microtonalismo e a Música Concreta, constituem todos a variedade de correntes musicais que começam a aparecer na música erudita do novo século.

De qualquer modo, para os períodos mais recuados da História da Arte - precisamente aqueles em que podemos identificar os chamados "estilos de época" - a utilização de conceitos como os elaborados por Heinrich Wölfflin para a análise pictórica mostra-se particularmente eficaz, desde que tenhamos plena consciência de seus limites. Podemos da mesma forma relacioná-los 
aos conceitos que aparecem mais habitualmente na análise musical, estabelecendo uma analogia entre a Música e a Pintura de cada período. A luz unidirecional que atravessa diagonalmente uma organização pictórica barroca é o equivalente ao tema musical que se movimenta incessante e sucessivamente através das diversas vozes musicais, e os espaços compartimentados da pintura renascentista, onde cada figura parece iluminar-se a partir de si mesma e adquirir contornos bem definidos, é bem o equivalente da superposição de seções musicais, cada qual com a sua luz e a sua temática própria, que pudemos ver nas composições musicais renascentistas. Para o caso do Renascimento e do Barroco, eis portanto alguns elementos iniciais para um estudo comparativo de dois estilos artísticos de época que se iluminam reciprocamente a partir de algumas oposições fundamentais, simultaneamente alcançados pela análise de duas formas de expressão artística distintas: a Música e a Pintura.

Um questionamento maior acerca do que estaria ligando cada uma destas estéticas - a Renascentista ou a Barroca - a um determinado contexto histórico-social mais amplo poderia encetar uma discussão posterior. Estes relacionamentos entre História, Sociedade e Arte através das várias produções pictóricas e musicais de cada período têm sido objeto de reflexão para estudiosos diversos. Muitos por exemplo relacionam a 'forma unitária' barroca que surge na civilização ocidental a partir do século XVII a um mundo histórico-social atravessado por projetos unificadores como o das grandes monarquias absolutas ou o das igrejas cristãs em disputa por um domínio pleno sobre o seu universo de devotos, fora a extraordinária ampliação dos horizontes intelectuais ocasionadas pelas novas descobertas científicas (o Barroco, reino da forma aberta, pode ser perfeitamente relacionado ao fascínio do homem pelo infinito que começa a ser descortinado pelas novas descobertas científicas $)^{17}$. Do mesmo modo, a busca de projetos unificadores, poderíamos ir mais além, estaria expressa no próprio traçado das ruas de uma cidade tipicamente barroca e na arquitetura de seus prédios. E ao estudo desta obsessão pela unidade, base de uma estética barroca unificadora, poderíamos acrescentar alguns outros aspectos fundamentais que aparecem tanto na pintura, como na arquitetura ou na música barroca - como por exemplo o gosto pelo adorno na arquitetura ou pelos ornamentos na música, estes bons representantes do desejo de assegurar a variedade a partir de uma unidade pré-estabelecida. De igual maneira, o jogo de tensões entre matéria e espírito, entre o profano e o divino, entre emotividade e razão, entre extravasamento e contenção, sempre controlados por uma poderosa estética de fundo unificador, eis aqui elementos que também poderão ser encontrados na arte desta mesma época.

Todos estes aspectos, enfim, da concepção unitária da obra atravessada por um incessante movimento unidirecional ao amplo uso do ornamento ou ao obstinado controle sobre os contrários, são expressões bem definidas de uma história e de uma sociedade específicas que acolhem os modos de expressão tipicamente barrocos. Raciocínios análogos poderiam se também elaborados para a busca de uma relação entre a arte e a sociedade renascentistas. Mas estes, certamente, constituiriam uma nova discussão, envolvendo diversificadas hipóteses e teorias.

\section{NOTAS}

01. Na mitologia grega, Apolo é na verdade também o Deus da Música, e teria vencido um duelo musical contra Pan. Contudo, para estabelecer a dicotomia entre apolíneo e dionisíaco, Nietzsche opta por agrupar em torno da imagem de Apolo o impulso de construir formas nítidas e bem delimitadas, que também é um de seus domínios, e contrapõe este impulso a embriaguez dionisíaca, na qual se encaixa muito bem a Música como arte abstrata por excelência. Referência: NIETZSCHE, Friedrich. O nascimento da tragédia. São Paulo: Companhia das Letras, 1996.

02. PANÓFSKY, Erwin. Arquitetura Gótica e Escolástica. São Paulo: Martins Fontes, 1991 [original: 1951]

03. SANZIO, Rafael. Escola de Atenas, 1509. Vaticano: Palácio do Vaticano, Stanza della Segnatura.

04. RUBENS, Petrus Paulus. O Rapto das filhas de Leucipo, 1618. ost. 222 x 219 cm. Munich: Alte Pinokothek. 
05. REMBRANDT, Harmenszoon van Rijn. Ronda Noturna, 1642. ost. Amsterdam: Rijksmuseum.

06. As diferenças entre a Música Renascentista e a Música Barroca tem sido tratadas por diversos autores. Para uma aproximação inicial, ver MOORE, Douglas. Guia dos estilos musicais. Lisboa: Edições 70, 1990. Para aspectos relacionados à interpretação musical, ver DART, Thurston. Interpretação da Música. São Paulo: Martins Fontes, 1990.

07. O modo de apresentação que em Música é denominado 'polifonia' - e que corresponde a várias vozes soando simultaneamente como melodias a serem percebidas dentro de sua identidade própria - pode ser contrastado com o modo de apresentação musical que denominamos 'homofonia'. Na Homofonia, tem-se uma melodia principal, geralmente na parte aguda, e um plano de acompanhamento em acordes que estabelece uma ambiência harmônica. / Sobre o desenvolvimento da polifonia na História da Música Ocidental, ver BOULEZ, Pierre. Apontamentos de aprendiz. São Paulo: Perspectiva, 1995, p.263270. Para uma compreensão acerca dos processos que permitiram que a Homofonia surgisse como conseqüência do posterior surgimento de uma linguagem harmônica na Polifonia Renascentista, ver WEBERN, Anton. Caminho para a Música Nova. São Paulo: Novas Metas, 1984.

08. Recomenda-se, para uma audição da música selecionada como exemplo, a interpretação gravada pelo Ensemble Clément Janequin em 1963 [JANEQUIN, Clément. Le Chant des Oyseaux. Paris : Harmonia Mundi, 1963. Ensemble Clément Janequin, HMC 901099. [CD-Rom]]. Referência da partitura: JANEQUIN, Clément. Le Chant des Oyseaux. [Paris: 1528]. New York: Broude Brothers, 1980.

09. Como exemplo de utilização da forma tipo rondó na música popular brasileira, pode ser examinado o célebre chorinho Odeon, de Ernesto Nazareth, que é construído com uma forma que pode ser esquematizada em cinco seções: A-B-A-C-A.

10. Não era incomum nos motetos medievais a superposição de textos em línguas distintas e com temáticas diversificadas. Por exemplo, podia-se ter no baixo uma melodia de apoio que correspondia a um canto gregoriano em latim, apresentando temática sacra, e em uma voz mais aguda um texto em francês com conteúdo amoroso ou erótico. Sobre o moteto medieval, ver BENT, Margaret. "The Medieval Motet." In Tess Knighton and David Fallows (orgs.). Companion to Medieval and Renaissance Music. New York: Schirmer Books and Maxwell Macmillan International, 1992. 114-19.

11. O moteto, de um lado, e o madrigal italiano e a chanson francesa, de outro, são gêneros muito aproximados no que se refere ao modo de apresentação musical, sempre uma polifonia vocal. Com relação à natureza do conteúdo poético que estes gêneros musicais encaminham, pode-se dizer que o moteto - pelo menos a partir do período renascentista - é sempre um gênero sacro, enquanto o madrigal ou a chanson constituem gêneros profanos. Com relação à forma musical, há diferenças sutis, como as que já foram mencionadas. Para um aprofundamento relacionado a estes genros da música renascentista, ver KIEFER, Bruno. História e significado das formas musicais. Porto Alegre: Editora Movimento, 1990.

12. Para um estudo mais aprofundado da Fuga na obra de J. S. Bach, ver MAGALHÃES, Homero. Bach - prelúdios e fugas I. São Paulo: Novas Metas, 1988.

13. Apesar da técnica análoga no que se refere à polifonia imitativa, há uma distinção formal importante entre as formas fugatas do barroco e o mero uso da polifonia imitativa na Música Renascentista mais típica. Conforme vimos no exemplo anterior, a unidade temática da música renascentista dá-se apenas no interior de cada seção, que a partir daí contrasta com as demais. $\mathrm{Na}$ polifonia barroca, um mesmo tema dita a unidade composicional da obra inteira.

14. Partitura: BACH, Johan Sebastian. Fuga $n$ 1 do "Cravo Bem Temperado - livro 1" [Leipzig: 1720]. Munich: Urtex, 2000; CD-Rom: BACH, Johan Sebastian. The Well Tempered Clavier Book 1. pianista: José Carlos Martins. Claremont (Califórnia): Concord, 1981.

15. Também Deleuze assim se expressa com relação a esta amálgama de tensões que, no Barroco, relacionam corpo e alma: "No Barroco, a alma tem com o corpo uma relação complexa: 
sempre inseparável do corpo, ela encontra nele uma animalidade que a atordoa, que a trava nas redobras da matéria, mas nele encontra também uma humanidade orgânica ou cerebral (o grau de desenvolvimento) que Ihe permite elevar-se e que a fará ascender a dobras totalmente distintas" (DELEUZE, Gilles. A dobra: Leibniz e o Barroco. Campinas: Papirus, 1991, p.26). As tensões entre corpo e alma, enfim, dão-se literalmente no mesmo lugar, e cada um destes pólos de tensionamento informa o outro. A oposição de elementos no Barroco, ousaríamos dizer, dá-se por contraditoriedade, e não como uma oposição de contrários como ocorre com o Renascimento.

16. Na verdade, as obras de arte, como a própria vida, de acordo com a filosofia nietzscheniana, são produzidas pela dialética do apolíneo e do dionisíaco. Cada obra de arte, grosso modo, elabora dentro de si, em alguma medida, os dois princípios. Para retomar as palavras de Nietzsche acerca da Origem da Tragédia: “... A seus dois deuses da arte, Apolo e Dionísio, vincula-se a nossa cognição de que no mundo helênico existe uma enorme contraposição, quanto a origens e objetivos, entre a arte do figurador plástico, a apolínea, e a arte não-figurada da música, a de Dionísio: ambos os impulsos, tão diversos, caminham lado a lado, na maioria das vezes em discórdia aberta e incitando-se mutuamente a produções sempre novas, para perpetuar nelas a luta daquela contraposição sobre a qual a palavra comum "arte" lançava apenas aparentemente a ponte; até que, por fim, através de um miraculoso ato metafísico da "vontade" helênica, apareceram emparelhados um com o outro, e nesse emparelhamento tanto a obra de arte dionisíaca quanto a apolínea geraram a tragédia ática..." (NIETZSCHE, Friedrich. O nascimento da tragédia. São Paulo: Companhia das Letras, 1996, p.72).

17. Os avanços científicos que já começam a ser impressos pelo Renascimento e a abrir novos horizontes começam precisamente a se entrechocar com o mundo da forma fechada, dos espaços compartimentados como os que vimos nas formas pictóricas e musicais da arte renascentista.

\section{REFERÊNCIAS}

\section{Visuais e sonoras}

$\mathrm{BACH}$, Johan Sebastian. Fuga n’ 1 do "Cravo Bem Temperado - livro 1" [Leipzig: 1720]. Munich: Urtex, 2000; CD-Rom: BACH, Johan Sebastian. The Well Tempered Clavier - Book 1. pianista: José Carlos Martins. Claremont (Califórnia): Concord, 1981

JANEQUIN, Clément. Le Chant des Oyseaux. Paris : Harmonia Mundi, 1963. Ensemble Clément Janequin, HMC 901099. [CD-Rom]

JANEQUIN, Clément. Le Chant des Oyseaux. [Paris : 1528]. New York: Broude Brothers, 1980

RUBENS, Petrus Paulus. O Rapto das filhas de

Leucipo, 1618. ost. $222 \times 219 \mathrm{~cm}$. Munich: Alte Pinokothek

REMBRANDT, Harmenszoon van Rijn. Ronda Noturna, 1642. ost. Amsterdam: Rijksmuseum.

\section{Bibliográficas}

BENT, Margaret. "The Medieval Motet." In Tess Knighton and David Fallows (orgs.). Companion to Medieval and Renaissance Music. New York: Schirmer Books and Maxwell Macmillan International, 1992. 114-19

BOULEZ, Pierre. Apontamentos de aprendiz. São Paulo: Perspectiva, 1995, p.263-270.

DART, Thurston. Interpretação da Música. São Paulo: Martins Fontes, 1990.

DELEUZE, Gilles. A dobra: Leibniz e o Barroco. Campinas: Papirus, 1991.

KIEFER, Bruno. História e significado das formas musicais. Porto Alegre: Editora Movimento, 1990

MAGALHÃES, Homero. Bach - prelúdios e fugas I. São Paulo: Novas Metas, 1988

MOORE, Douglas. Guia dos estilos musicais. Lisboa: Edições 70, 1990.

NIETZSCHE, Friedrich. 0 nascimento da tragédia. São Paulo: Companhia das Letras, 1996 
PANÓFSKY, Erwin. Arquitetura Gótica e

Escolástica. São Paulo: Martins Fontes, 1991 [original: 1951]

WEBERn, Anton. Caminho para a Música Nova.

São Paulo: Novas Metas, 1984.

\section{SOBRE O AUTOR}

José Costa D'Assumção Barros é doutor em História pela Universidade Federal Fluminense (1999), mestre em História pela Universidade Federal Fluminense (1994), graduado em História pela Universidade Federal do Rio de Janeiro (1993) e graduado em Música (Composição Musical) pela Universidade Federal do Rio de Janeiro (1989). Professor Adjunto da Universidade Federal Rural do Rio de Janeiro (UFRRJ). Na área de História, tem atuado principalmente com temáticas ligadas às seguintes áreas: Historiografia, Teoria da História, Metodologia da História, História Cultural, História da Arte, Cinema-História. Na área de Música, tem desenvolvido pesquisas na área de Musicologia Histórica e História da Música. Publicou 20 livros e cerca de cento e cinquenta artigos, trinta dos quais em revistas internacionais (Portugal, Espanha, Itália, Dinamarca, Canadá, Estados Unidos). 